\title{
Lessons from the past: the collapse of Jamaican coral reefs
}

\author{
Marah J. Hardt \\ Blue Ocean Institute, PO Box 250, East Norwich, NY 11782, USA
}

\begin{abstract}
Since Pre-Columbian times, humans have exploited Jamaican marine ecosystems with significant consequences for flora and fauna. This study focuses on the history of reef fish exploitation in Jamaica, from first human occupation to the present day, to determine how past fishing activities contributed to subsequent declines in the coral reef ecosystem. The pattern of declining reef fish populations was nonlinear. Reef fish first declined in prehistoric times but then potentially recovered, following genocide of the native human population. Reduced fishing pressure lasted until the mid-19th century. At that time, depletion of reef fish populations again occurred with a precipitous decline from the 1850 s to the 1940s. The final shift from relatively abundant to overfished marine fauna corresponded to subtle changes in fish trap design as well as development of recreational fishing. Government subsidies throughout the second half of the 20th century exacerbated the declines. This analysis shows that local artisanal fisheries with relatively low levels of effort and seemingly subtle shifts in technology can significantly impact the coral reef ecosystem and that declines occurred decades to centuries before modern ecological studies began. This research shows how historical analysis can be a powerful tool to minimize shifted baselines and establish realistic targets for recovery and sustainable management of marine ecosystems.
\end{abstract}

Keywords Caribbean reef fish, coral reef degradation, historical ecology, overfishing

\author{
Correspondence: \\ Marah J. Hardt, Blue \\ Ocean Institute, PO \\ Box 250, East \\ Norwich, NY 11732, \\ USA \\ Tel.: + 1516922 \\ 9500 \\ Fax: + 1516922 \\ 9505 \\ E-mail: mhardt@ \\ blueocean.org \\ Received 8 Jan 2008 \\ Accepted 11 Sep 2008
}

$\begin{array}{lr}\text { Introduction } & \mathbf{2} \\ \text { Materials and methods } & \mathbf{2} \\ \text { Results } & \mathbf{2} \\ \text { Pre-European: Ostionan (AD 600-900) and Meillican (AD 900-1500) } & 2 \\ \text { Spanish occupation: 1509-1655 } & 4 \\ \text { English colonization: } 1656-1832 & 4 \\ \text { Post-emancipation: } 1832-1900 & 6 \\ \text { Trap fishery: 1900-1950 } & 8 \\ \text { Modern era: } 1950-2006 & 9 \\ \text { Discussion } & 10 \\ \text { Acknowledgements } & \mathbf{1 3} \\ \text { References } & \mathbf{1 4}\end{array}$ 


\section{Introduction}

"Ebry day da fishing day, but ebry day no fe catch fish".

19th century Jamaican Proverb (Rampini 1873) Jackson (1997) highlighted the value of historical documents to illuminate the degree of anthropogenic disturbance in marine environments over a decade ago. Since then, several ecologists have mined unconventional sources to reconstruct orders of magnitude losses in marine ecosystems associated with human exploitation (Dayton et al. 1998; Jackson et al. 2001; Pandolfi et al. 2003; Rosenberg et al. 2005; McClenachan et al. 2006a; SáenzArroyo et al. 2006; Lotze 2007; McClenachan and Cooper 2008).

The collapse of Jamaican coral reefs - attributed to initial overfishing followed by successive hurricanes and sea urchin disease - has been extensively studied (Woodley et al. 1981; Hughes 1994). However, coral disease, bleaching events and degraded water quality have also been proposed as the main causes of degradation (Lapointe 1997; Aronson et al. 2003). This dispute highlighted the need for a longer term perspective with which to evaluate the collapse. Previous historical analyses revealed overfishing of turtles and manatee in the 17th century and loss of megafauna such as crocodiles, sharks and the now extinct Caribbean monk seal (Monachus tropicalis, Phocidae) in the late 19th century (Hughes 1994; Jackson 1997; Pandolfi et al. 2003; McClenachan et al. 2006a), but detailed examination of trends in reef fish populations and the cause of their declines are less well defined.

This research provides an in-depth analysis of history of fishing and associated changes in reef fish populations in Jamaica from around AD 600 to the present day. Combining evidence from archaeological, historical and ecological resources, this work constructs the first detailed picture of fishing pressure on Jamaican coastal ecosystems over the past 1400 years. The analysis presents a complete trajectory of coral reef ecosystem change - from living abundance to severe collapse. This trajectory can serve as a reference against which change in other coral reef ecosystems across the globe can be compared.

\section{Materials and methods}

Data were garnered from published and unpublished archaeological reports, plantation records, government reports, sociological studies and recent scientific research. In addition, information from numerous published accounts of island visitors, residents, naturalists, plantation owners and government officials was also used. Many of these sources were rare books accessed through specific inter-library loan permissions granted through the Scripps Institution of Oceanography library.

The history of human occupation in Jamaica was divided into seven time periods based on socioeconomic and cultural events (Table 1). For each time period, information was gathered on the types of fishing gear employed, habitat accessed and the marine life exploited, including offshore species. Many references included names no longer in use. Identification of species was conducted using published taxonomies and by consulting the curators of the fish collection at the Scripps Institution of Oceanography. Where species or genera could not be determined, family names were used.

By amassing a database from many records (over 150 independent sources), trends in the level of exploitation, the historical context in which they occurred, and the corresponding status of marine fauna over time can be examined. Descriptions of past faunal communities were also compared with the earliest modern quantitative fisheries data (1960s, Munro 1983) and an ecological survey conducted on the north coast of Jamaica in February, 2005 (Newman et al. 2006).

\section{Results}

\section{Pre-European: Ostionan (AD 600-900) and Meillican (AD 900-1500)}

Jamaica was colonized by the Ostionan people sometime between $\mathrm{AD} 600$ and 800. This villagebased society was joined (or replaced) by a Meillacan period people in around AD 900. Rapid population growth led to multiple large villages with over 2000-3000 people each by AD 1000 (Wilson 1997). Estimates of the total population of Jamaica at the time of European arrival in the late 15th century range from 100000 to 1 million, with estimates of 600000 considered conservative by some experts [Las Casas 1552 reprinted (1974); Black 1965; Watts 1987; K. Wesler, personal communication].

Like most Caribbean islands, Jamaica lacked large terrestrial mammals; so, the relatively dense popu- 
Table 1 Summary of major characteristics of each time period.

\begin{tabular}{|c|c|c|c|}
\hline Time period & Date & Description & Major references \\
\hline Pre-European & $\begin{array}{l}600-900 \\
\text { (Ostionan) } \\
900-1500 \\
\text { (Meillacan) }\end{array}$ & $\begin{array}{l}\text { Large human population led to declines of nearshore } \\
\text { marine fauna and exploitation of offshore species. }\end{array}$ & $\begin{array}{l}\text { O’Day (2001), Wilson (1997), } \\
\text { Scudder (1991), Carlson } \\
\text { (2001, 2002), Rouse (1992) }\end{array}$ \\
\hline $\begin{array}{l}\text { Spanish } \\
\text { occupation }\end{array}$ & $1509-1655$ & $\begin{array}{l}\text { Spanish arrival and mass depopulation of native inhabitants; } \\
\text { continued pressure on turtle and manatee but no evidence } \\
\text { of fishing reef fish; likely recovery of finfish populations } \\
\text { during this time. }\end{array}$ & $\begin{array}{l}\text { Fernández de Oviedo y Valdés } \\
\text { and Pérez de Tudela y Bueso } \\
\text { [1526 (1959)], Las Casas } \\
\text { [1552 (1974)] }\end{array}$ \\
\hline $\begin{array}{l}\text { English } \\
\text { colonization }\end{array}$ & $1656-1832$ & $\begin{array}{l}\text { Rise and fall of slave society, massive population increases; } \\
\text { slowly increasing use of reef fish using nets, hook and line } \\
\text { and poisoned bark. }\end{array}$ & $\begin{array}{l}\text { Sloane (1707-1725), Dampier } \\
\text { [1729 (1968)], Long (1774), } \\
\text { Dunn (1972) }\end{array}$ \\
\hline $\begin{array}{l}\text { Post- } \\
\text { emancipation }\end{array}$ & $1832-1900$ & $\begin{array}{l}\text { Increase in subsistence fishing with use of seines, pots, hook } \\
\text { and line and long-lining; noticeable shift in catch composition } \\
\text { to fewer large fish and top predators and more offshore } \\
\text { species by late 19th century; human population reaches } \\
\text { Pre-Columbian estimates. }\end{array}$ & $\begin{array}{l}\text { Stewart [1823 (1969)], Williams } \\
\text { (1827), Gosse (1851), Duerden } \\
\text { (1901), Senior (1969) }\end{array}$ \\
\hline Trap fishery & $1901-1945$ & $\begin{array}{l}\text { Advent of tourism and sport fishing; introduction of chicken } \\
\text { wire mesh led to increased pot fishing over seine nets; } \\
\text { Jamaica's fisheries officer Thompson declares overfished } \\
\text { nearshore reefs in } 1945 .\end{array}$ & $\begin{array}{l}\text { Beckwith (1929), Thompson } \\
\text { (1945), Comitas (1962) }\end{array}$ \\
\hline Modern era & 1946-2006 & $\begin{array}{l}\text { Rise of government subsidies, movement to offshore reefs, } \\
\text { continued declines in fish populations, development of } \\
\text { modern coral reef science. }\end{array}$ & $\begin{array}{l}\text { Kirton (1961), Munro (1969, 1983), } \\
\text { Aiken and Haughton (1987), } \\
\text { Koslow et al. (1988), } \\
\text { Hughes (1994) }\end{array}$ \\
\hline
\end{tabular}

lations of early natives relied upon horticulture and fishing for food (Keegan 2000; Wing and Wing 2001). Analysis of kitchen middens (food refuse piles) provides detailed, species-specific information on patterns of consumption during these two cultural periods. A comparison of these middens reveals three lines of evidence that suggest a decline in nearshore marine resources during the later (Meillican) period. First, there is a shift to smaller food packets. Sea turtle (Chelonidae), crocodile (Crocodylus sp., Crocodylidae), shark (Carcharhinus sp. Carcharhinidae and Ginglymostoma cirratum, Ginglymostomatidae) and manatee (Trichechus manatus, Trichechidae) were far less abundant in the later sites than in earlier middens, where they had comprised up to $90 \%$ of the biomass (O'Day 2001; Carlson 2002).

Second, analyses of the Meillican middens in the north coast sites show an increase in terrestrial fauna in later (more recent) levels of remains. Marine taxa decreased from $57 \%$ of species to $31 \%$, replaced by small terrestrial mammals. In addition, there is an increased dominance of large tuna, indicating that people were travelling further offshore to obtain food (Allgood 2002).
Third, using the size of vertebra and published weight-length relationships, comparison of two middens from the same site dated $\mathrm{AD} 850$ and 1430 reveals that average fish size decreased from $1.2 \mathrm{~kg}$ to $300 \mathrm{~g}$ and the majority of the carnivorous species present in the later middens were remains of small individuals, probably juveniles (O'Day 2001; Carlson 2002; Carlson and Keegan 2004). Also herbivores, mostly parrotfish (Scaridae), increased in abundance compared with predatory fish such as groupers (Serranidae), snappers (Lutjanidae) and jacks (Carangidae).

There is no evidence for technological or diet preference changes that might account for these shifts. Instead, the pattern is consistent with predicted theoretical shifts due to overfishing: decreased abundance and size of preferred, carnivorous species such as grouper, snapper and jacks; decreased abundance of more vulnerable large fauna such as sea turtle, manatees, crocodiles and sharks; and a shift to increased dependence on terrestrial or offshore species (Butler 2001; Wing and Wing 2001). Thus, archaeological evidence in Jamaica shows that relatively minimal effort - a fraction of the modern population size using very 
primitive gear - considerably degraded the marine environment long before European contact.

\section{Spanish occupation: 1509-1655}

Spanish occupation of Jamaica in 1509 brought disease and harsh treatment of the natives, leading to rapid human population declines [Las Casas 1552 (1974); Crosby 2003]. Unlike the British who established permanent colonies, the Spaniards used Jamaica as an outpost to support mining of gold and silver on the mainland (Gardner 1909). By the mid17 th century, only one town existed and the total island population was 5000 (Long 1774; Pietersz 1945-1948). The introduction of hogs and cattle provided a protein source other than fish. No evidence of exploitation of reef fish during this time period was found, although investigation of Spanish documents would be particularly helpful. The extremely reduced human population and the availability of terrestrial protein, more familiar to Spanish settlers, greatly decreased the demand for marine-based food, providing a respite for reef fish.

By contrast, the two largest herbivores of Jamaica's reef and seagrass communities, green turtle (Chelonia mydas, Chelonidae) and manatee, were hunted in great numbers during Spanish occupation. Fisheries for sea turtle and manatee were widespread throughout the Caribbean during the 16th and 17th centuries (Ober 1891; Jackson 1924; Andrews 1959), including Jamaica [Fernández de Oviedo 1526 reprinted (1959)]. Sea turtles were especially sought after by sailors, who kept them alive on their backs to assure a fresh meat supply during long journeys (Andrews 1959).

By the mid-17th century, human interaction with the marine environment had already run a complicated course. Archaeological and historical analyses indicate that the coral reefs of Jamaica contained an abundance of large $(>1 \mathrm{~kg})$ predatory fishes and large herbivores when humans first occupied the island (O'Day 2001; Allgood 2002; Carlson and Keegan 2004). Other lower trophic level species such as hogfish (probably Lachnolaimus or Bodianus spp., Labridae), parrotfish, surgeonfish (Acanthuridae) and grunts (Haemulon sp., Haemulidae) were also present in large quantities and increased in importance as food sources over the first few hundred years of habitation. This is probably the result of declining abundance in preferred carnivorous species (Carlson 2002). Reduced pressure on finfish populations during the
150 years of Spanish occupation may have helped depleted finfish to recover, but increased pressure on turtle and manatee led to significant declines in these two herbivores by the late 17 th century (Sloane 1707-1725).

\section{English colonization: 1656-1832}

During the English occupation, Jamaica developed from a buccaneering headquarters to a productive sugar colony that depended heavily on a large number of African slaves (Dunn 1972; Crosby 2003). Between 1660 and 1713, the slave population of Jamaica increased from 500 to 55000 and by 1810 , the total slave population exceeded 300000 of a total island population of approximately 400000 people (Craton and Walvin 1970; Dunn 1972; Higman 1998).

This rapid growth in population demanded a food source that was readily available, inexpensive and could withstand inland transport in tropical climates. Catching fish locally was too time consuming, too expensive and the fish fell to pieces when dried or salted for preservation (Dunn 1972).

The answer was found in salt fish, which the naturalist Dr Hans Sloane explained, 'comes from New England and is much used in this Island for the support of Slaves and Servants' (Sloane 17071725). For North American salt cod merchants, the slaves of the Caribbean offered a ready market for their lowest quality product, which came to be called 'West India' (Kurlansky 1997). In Jamaica, European colonists also eagerly purchased higher quality salt fish in an attempt to maintain a diet similar to that of their homeland (Innis 1954). By the late 17 th century, salt fish was entrenched in the plantation economy and palate of slaves and colonists in Jamaica. Thus, in a twist of fate, Jamaican coral reef fish were largely spared at the great expense of their North Atlantic cod, herring and mackerel brethren.

Although reef fish did not bear the brunt of feeding this rapidly growing population, there is evidence for limited but increasing use of local marine resources during this time, and signs that even this limited pressure caused changes in reef fish communities.

In general, as in other Caribbean islands, slaves consumed minimal amounts of local fish themselves and wealthy colonists would eat the local varieties on special occasions (Long 1774; Price 1966; Dunn 1972). In the early 18 th century, those species that 
Figure 1 Illustrations of several marine species from Sloane (17071725 , table 253). The upper fish is the 'Rockfish', probably a grouper (Serranidae); the middle fish is called the 'Stone bass' (possibly Gerreidae) and the bottom fish is 'Dentici congener piscis,' probably a snapper (Lutjanidae) based on the description and drawing.

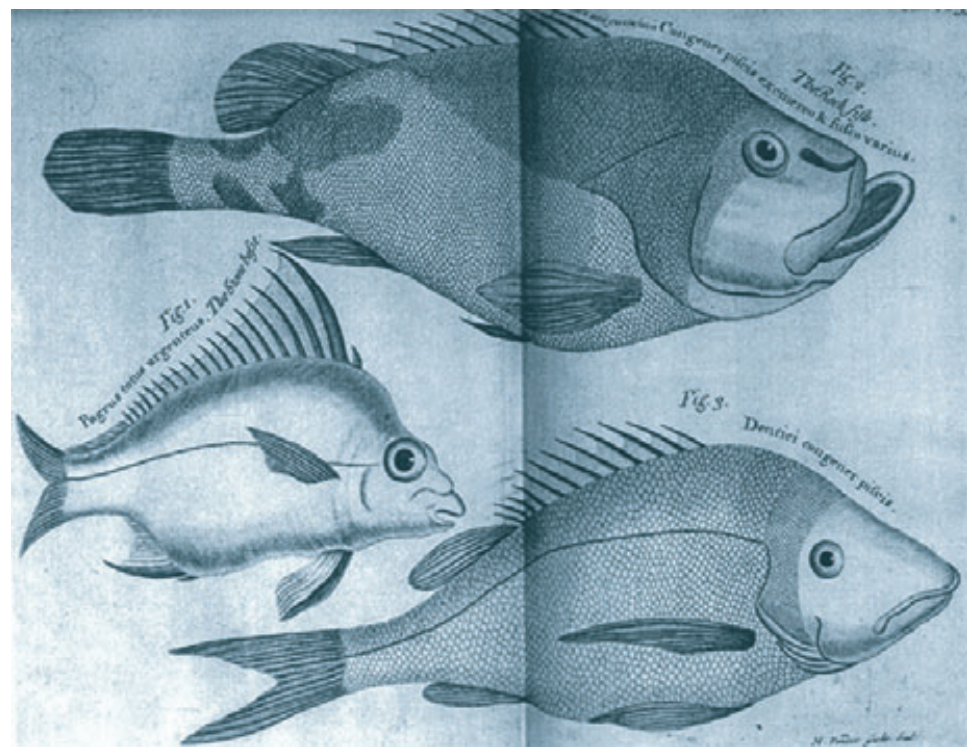

were 'brought to market,' 'good to eat' and 'welltasted' included 'Spanish Mackarel' (probably Scomberomorus maculates, Scombridae), 'Barracuda' (probably Sphyraena barracuda, Sphyraenidae), 'Stone bass' (uncertain but possibly Gerres sp., Gerreidae) and the 'Rock fish' (probably Serranidae) (Fig. 1, Sloane 1707-1725). Most of the species mentioned are large predators on the reef and as will be discussed later, most are missing from modern surveys (Newman et al. 2006).

Seventy years later, similar large, carnivorous species such as Spanish mackerel, grouper, jack and snapper, as well as parrotfish, 'porgee' (probably Sparidae), and sting rays (probably Dasyatidae or Urolophidae) are listed as 'esteemed' by the historian Edward Long (1774).

Even though local fish consumption was minimal, there were government regulations for fishing activities and trade (Long 1774). Published laws stated: "no person, by himself, servant, or slave, is to destroy fish in any harbour, bay, creek or river by poisoning or intoxication; ...nor make use of any seine, net or engine for catching fish, in any harbour or pond, etc., with less mesh than one inch and a quarter between knot and knot, except shrimp-nets...' (Aikman 1787). Long (1774) gives the date of this law as 1711. The designation of a minimum mesh size is frequently a measure taken to prevent overfishing of small species or juveniles. Such action is often taken when there is evidence of population declines (Munro et al. 1971). Recent historical studies confirm that scarcity of a resource, rather than an abundance, tends to drive development of such regulations (K. Alexander, unpublished research, personal communication). Thus, while the motivation behind these regulations is not entirely clear, it is probably a reflection of perceived limitations in fish populations.

At the beginning of the 19th century, new largescale-directed fishing efforts are described for the first time. Resident of Jamaica, Alexander Barclay wrote in 1828 that:

$[\mathrm{m}]$ any of the larger properties on the sea-coast get a seine annually from England, which is drawn every morning to procure a dish of fish for the plantation. Eight or ten fishermen from different estates in the same neighbourhood...join in drawing the seine, and each gets a dish of fish for the estate to which he belongs... what may be over a dish to each estate, they keep for their own use... (Barclay 1828).

The use of large seine nets required organized effort of multiple slaves. Such coordination introduced a new level of fishing intensity onto the reefs. These seine hauls caught 'an immense quantity of fish...sufficient to fill a canoe,' including jacks, snappers, barracudas, trunkfish (Ostraciidae) and an unidentified species called 'silver oldwives' (Williams 1827). The wealthy masters partook of the 'most delicate' species, while the slaves were entitled to the rest, which they later sold in the local markets.

The first direct evidence of trap or 'pot' fishing in freshwater and marine environments occurs early 


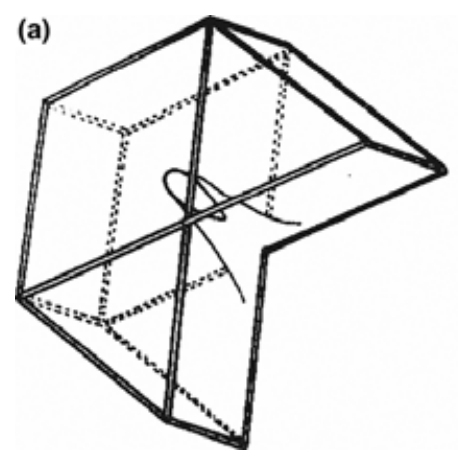

(b)

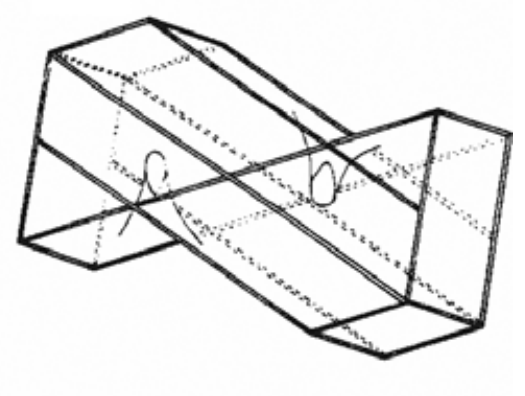

Figure 2 Trap designs through time: (a) Chevron trap (single box), approximately $61 \mathrm{~cm}^{2} \times 30.5 \mathrm{~cm}$ deep, primarily wicker (Gosse 1851); (b) Z trap, approximately 177 $230 \mathrm{~cm}$ long, $102 \mathrm{~cm}$ wide, $61 \mathrm{~cm}$ deep, primarily of wire mesh $3.7-$ $4.13 \mathrm{~cm}$ size (Munro et al. 1971 by permission of the Gulf and Caribbean Fisheries Institute). in the 19th century. The traps were probably of the same type as described later by Gosse in 1851 (see next section, Fig. 2). These were $1.2 \mathrm{~m}^{2} \times 0.3 \mathrm{~m}$ deep and made of interwoven strips of wood. These were commonly used in the rivers where 'every little stream, and every mill course, is full of these traps...fish are likewise very plentiful among the rocks along the sea-shore, and are caught there with traps set in the same manner as in the deep pools of the rivers' (Barclay 1828).

In the first few decades of the 19th century, species such as 'Jew-fish [Epinephelus itajara, Serranidae], hog-fish, mud-fish, snappers, god-dammies, groupas, and grunts' and 'the Deep-water Silk [likely Lutjanidae]' were considered the tastiest and best [Stewart 1823 reprinted (1969); Lewis 1834]. All of these species, except the grunts, are top predators on coral reefs (although 'mud-fish' and 'god-dammies' remain a mystery). Yet, while these seem to be the favoured fish, other species, such as trunkfish and parrotfish, were also caught during this time.

During the 1820s and 1830s, 'almost every estate ha[d] a negro employed as a fisherman...' (Barclay 1828). As in the late 18th century, slaves fished to 'furnish a supply of fish, and sometimes prawns and crawfish, to the proprietor's or overseer's table' with some limited consumption themselves (Senior 1969). In a very few circumstances, slaves fished to earn profits for the plantation (Higman 1976).

Although only a small portion of the population, slave fishermen established directed, routine fishing pressure in river and marine environments. By 1823, 'nearly a hundred different species of sea and river fish might be enumerated that are caught and used by the inhabitants (of Jamaica)' [Stewart (1823 1969)]. By the early 19th century, fishing in Jamaica had increased in sophistication and regularity compared with that of the previous few centuries - such effort was the first real organized fishing pressure on finfish in over 300 years (Barclay 1828; Higman 1998).

The history of fishing effort for other marine species differed from finfish, especially for green turtle and manatee. Explorer and sophisticated buccaneer Sir William Dampier commented that Jamaica was 'constantly supplied' by 'the turtle that live among the Keys, or small Islands on the South Side of Cuba' [Dampier 1729 reprinted (1968)]. The dependence on imports from nearby islands suggests that Jamaica's own stocks were depleted. This is supported by evidence of a Jamaican law, passed in 1711 , that prohibited the destroying of turtle nests or taking of turtle eggs in Jamaican territories (Long 1774; Aikman 1787). By the late 1700s, turtle populations in waters neighbouring Jamaica, namely the Cayman islands and Cuba cays, were also exhausted, forcing the fishery to move south to the islands off of Nicaragua (Parsons 1956; King 1981).

As early as the 1680s, manatee populations in Jamaica were also noticeably reduced. According to Sloane, writing in the 1680 s, manatee 'have formerly been frequent but are, by the multitude of people and hunters catching them, destroy'd' (Sloane 1707-1725). The loss of these two large herbivore species has been calculated to have had major ecosystem consequences, especially for seagrass communities (McClenachan et al. 2006a).

\section{Post-emancipation: 1832-1900}

Immediately following emancipation, fishing was a relatively minor industry conducted by a small portion of the population (Gardner 1909; Colonial Secretary 1911, 1921; Higman 1980). Salt fish and other imported goods were the major staples of the 
local diet despite the perception that the waters around Jamaica, abound with some of the finest fish in the world...' [Bigelow 1871 reprinted (1970)]. Unlike other Caribbean islands, freed slaves in Jamaica (the third largest Caribbean island) benefited from the available abundance of undeveloped land and quickly established a free peasantry society (Butler 1995).

Yet, even though the fishery was small and gear simple, early signs of depleted nearshore reef fish communities appear during the second half of the 19th century. The naturalist Philip Henry Gosse in the 1840s described the seine as the 'chief resource of the fisherman' which brought in the 'usual abundance' of grunts, snappers, hamlets (Hypoplectrus sp., Serranidae) and hinds (probably Epinephalus sp., Serranidae), along with parrotfish, butterflyfish (Chaetodon sp., Chaetodontidae), 'Doctor-fish' (probably Acanthurus chirurgus, Acanthuridae), trunk fish, 'hedge-hog' (porcupine fish, Diodontidae), young sharks and eels (probably Moraenidae). Sometimes the nets were dragged with the use of a canoe up to a mile offshore with a significant effect on the shallows: "young sharks were prodigiously numerous on this coast... At the rate at which the fishing-canoes brought them in with other fish taken in the seines daily, not less than ten thousand of them must be annually destroyed upon this beach alone' (Gosse 1851).

Trap fishing tended to catch 'only fish of small and middling size,' including small demersal fish of all varieties, such as porcupine fish, mullets (Mugilidae), angelfish (probably Pomacanthus sp. and/or Holocanthus sp., Pomacanthidae), snappers, grunts, Cobia (Rachycentron sp., Rachydentridae) and scorpion fish (Scorpaenidae) (Gosse 1851).

Line fishing developed during the late 19th century and caught snappers and grunts, which 'bite freely at a bait of Sprat (Harengula cupeola [Clupeidae]).' Larger fish were caught with specially baited wire hooks (Gosse 1851). Jamaicans also used an early form of long lining, the palenka, that was a 'line of almost interminable length, with any number of hooks affixed to it...the largest has 550 hooks on it, at 2 3/4 yards apart, which gives nearly a mile in length of fishing line..., which targeted carnivorous reef fish species (Rampini 1873).

Comparison of mid-19th century catches with earlier descriptions reveals several differences. According to Gosse (1851), the most esteemed fishes for the table, and the most common, are the Snappers, Yellow-tails, Silks, and Hinds (various species of Serranina or Marine Perches), and the Grunts and Squirrels (species of Sciaenidae).' These contrast with the larger predatory species such as hogfish, jack and larger grouper that were described as favoured and common in the 18th and early 19th century. The absence of the Jewfish is particularly noteworthy. This fish was mentioned as plentiful by Dampier in the late 17th century, as tasty and plentiful by Lewis in 1815, and 'reckoned [one of] the best' by Stewart in 1823. However, Gosse does not mention it, neither in his description of common fish or in the most esteemed. Given the life-history characteristics (slow growth and late maturation) and preference for this species in earlier decades, it may have been locally depleted by the mid-19th century. In addition to fish, Gosse (1851) notes that crocodiles were rare in many parts of the island, fishermen had begun to target adult sharks for their liver, and the Caribbean monk seal was no longer found on mainland Jamaica.

An official list of 'common' species, produced in 1898 under the auspices of the Caribbean Fisheries Development Syndicate, shows a continued trend towards increasing abundance of smaller, lowertrophic level species. During a 1896 survey, 'the most usual and common' fish obtained around Jamaica were 'various species of snappers (Mesoprion sp.), yellow-tail (Ocyrurus chrysurus), grunts (Haemulon), drummers, (Larimus, Micropogon) and silks (Tropidinius dentatus) [likely Lutjanidae]' (Duerden 1901). Although considered 'high quality', the majority of reef fish species listed are all relatively small and feed predominantly on small fishes, molluscs and other benthic invertebrates. The absence of groupers, jacks and other top predators from these lists may indicate initial local declines as a result of continued trap, seine and hook and line fishing. Seine nets, which had been employed for decades were also found to yield "little more than sufficient fish to employ the few men at present engaged' (Duerden 1901).

The use of traps and seines, which catch fish indiscriminately, in nearshore environments that are often nursery habitats for juvenile reef fish species may have had deleterious effects on local finfish populations in the late 19th century. Gosse's notes on the small size of fish in traps and the large number of juvenile sharks caught with beach seines suggest that immature fish were often targeted. Effects may have been particularly harmful for slowgrowing, late-maturing species, with naturally low recruitment rates such as sharks. 
Changes in technology and catch composition in the late 19th century also indicate a spatial expansion of the fishery during this time. Seine nets set up to a mile offshore and long lines permit access to reef habitat further from shore. In addition, the government survey lists 'King fish' and 'June fish' as common 'migratory species.' These two species are most probably one of the open water species of mackerel (potentially King mackerel, Scomberomorus cavalla) and wahoo (Acanthocybium solandri, Scombridae) that are known to make spawning run-offs of Jamaica's northeast coast in May and June.

The dominance of small carnivores and omnivores on the list of 'common' fish and expansion of the fishery to target offshore reef environments and migratory species strongly support claims that nearshore reef fish of Jamaica were already in decline prior to the 20th century (Jackson 1997; Pandolfi et al. 2003). This evidence of decline coincides with a human population size in 1891 similar to PreColumbian estimates of 600000 (Watts 1987).

\section{Trap fishery: 1900-1950}

Continued rapidly growing human population increased demand for a reliable food supply. Pressure on the reefs increased as Jamaicans caught and sold more fresh fish in exchange for salt fish, their preferred food (Duerden 1901; Thompson 1945). In addition to fish, corals, sea fans and other 'curios' were also harvested and sold to tourists in order to purchase salt fish (Leader 1907; Beckwith 1929).

By the 1920s, 'sea fishing [was] carried on to a considerable extent in Jamaica' and was the full-time occupation of many seacoast villagers (Beckwith 1929). As the fisheries developed in the villages, so too did the technology. The use of a spritsail with canoes allowed access to reefs farther from shore, and also decreased travelling time between locations (Beckwith 1929). The most significant change to the fishery was the introduction of low-priced, readily available chicken wire, which allowed fishermen to construct larger, longer lasting traps (Munro et al. 1971). Chicken wire quickly replaced wicker mesh and allowed for trap size to double from 'single box' (probably a chevron design) to a 'double box' pattern, probably the Z trap in use today (Fig. 2) (Beckwith 1929). With these changes, trap fishing replaced seine nets as the dominant form of fishing by 1930 (Beckwith 1929; Thompson 1945).
The new Z traps could catch larger sized fish and twice as many fish as the previous trap design (Munro et al. 1971). In addition, as chicken wire does not degrade as rapidly as the original wicker, lost traps can continue to catch and kill fish for extended time periods, magnifying the effect of trap fisheries on bottom communities (Olsen et al. 1978). In Jamaica, (then and today), the rate of trap loss is high (Thompson 1945). Moreover, the increased availability of cheap supplies such as wire mesh encouraged construction of traps even for occasional use. Because the typical canoes of Jamaica fishermen were restricted in range to nearshore reefs, this limited area had to absorb the increased fishing pressure.

Sport fishing also developed during this time period bringing new fishing effort to the remaining large predators in rivers, estuaries, nearshore reefs and offshore. Artisanal fishermen tended to avoid catching these species due to their large size, locations offshore or because they were not considered good food fish (such as tarpon, Megalops atlanticus, Megalopidae). Visitors praised Jamaica as having the best variety of deep sea and river sport fishing, targeting tarpon, jack, grouper, snook (Centropomus undecimalus, Centropomidae), crocodiles and sharks (Collier 1938; Lee 1933; Verrill 1931). Descriptions such as 'tarpon weighing as much as one hundred pounds, snappers weighing over one hundred pounds, enormous groupers, jacks up to twenty-five pounds, and snooks weighing fifteen pounds are not unusual' (Verrill 1931) indicate that up until the 1930s, such large predators could still be found in Jamaican waters. All these changes had major consequences for reef fish populations.

By 1945, government fisheries scientist, Dr Ernest F. Thompson, declared 'there is little prospect of any large increase in this local catch. In fact, the probability is that the local areas are already overfished.' This is the first official statement of degraded reef fisheries in Jamaica and contrasts greatly with previous descriptions of Jamaica's marine resources (Table 2). This noted decline followed 150 years of organized, artisanal fishing effort and happened only 20 years after the introduction of wire mesh, increased trap size and the development of a popular recreational fishery. In 1945, 'fishermen got as much fish from six pots [15-20 years ago] as they now get from fifteen or twenty pots' (Thompson 1945). The reef ecosystem also suffered from destructive fishing practices 
Table 2 A series of quotes showing decreased fish abundance over time.

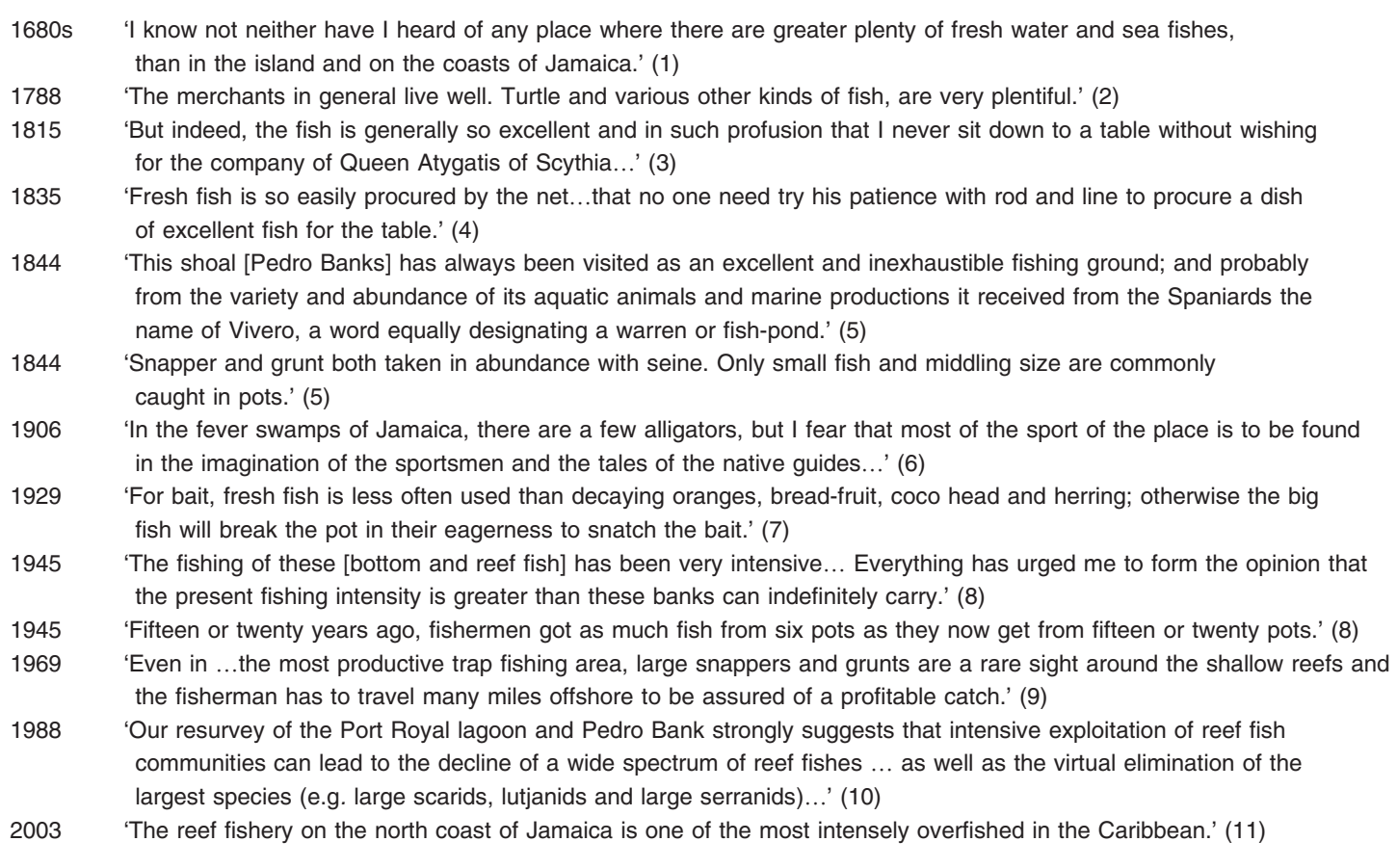

(1) Sloane (1707-1725, Intro p. xviii); (2) Marsden (1788, p. 12); (3) Lewis (1834, p. 67); (4) Senior (1969, p. 69); (5) Gosse (1851, p. 311); (6) Henderson (1909, p. 132); (7) Beckwith (1929, p. 32); (8) Thompson (1945, pp. 17-18); (9) Munro (1969, p. 20); (10) Koslow et al. (1988, p. 355); (11) Sary et al. (2003, p. 98).

including dynamiting and poisoning during this time (Hickling 1949).

The declining catches and decreased salt fish imports due to World War II led to government initiatives to increase the supply of locally caught protein. These initiatives only exacerbated the already increased pressure on the reefs due to human population growth, trap design and recreational fishing. Such policies were in direct contrast to Thompson's recommendations in 1945, which argued that 'the greatest need for the Jamaican fishermen is more in the nature of welfare than development' and urged for programmes to help ease fishermen out of the industry. It was here in Jamaica during the 1950s and 1960s, under these conditions of degraded fish communities that the foundations for coral reef ecology were laid.

\section{Modern era: 1950-2006}

The most significant development during the latter half of the 20th century was the spatial expansion of the fishery to outer reefs (>24 $\mathrm{km}$ from shore) and offshore banks, facilitated by government sub- sidies. Until this period, the offshore reefs were a largely untapped resource for trap and line fisherman (Gosse 1851; Gordon 1964) and may have served as a source of recruitment for nearshore reef fish populations. In the 1950s and 1960s, the government sponsored a boat mechanization scheme to subsidize outboard engines and gasoline/oil and develop programmes to train fishermen 'in the use of improved gear and equipment' (Kirton 1961). These programmes succeeded in creating a $50 \%$ increase in landings and, by the 1970 s, the outer reefs and banks were subjected to 'fairly regular, although not intensive' exploitation by canoes from Jamaica (Munro 1969).

The increased catch came at a great expense for many reef fish species. By the mid-20th century, the dominant fish in traps were parrotfish, surgeonfish and grunts with squirrelfish, butterflyfish and damselfish (Pomacentridae) commonly caught (Munro et al. 1971, Munro 1983). By 1969 'large snappers and grunts [were] a rare sight around the shallow reefs and the fisherman [had] to travel many miles offshore to be assured of a profitable catch' (Munro 1969). 
The government issued additional subsidies for boats, engines, fuel and gear (including for wire mesh in 1976) throughout the 1970s and 1980s (Aiken and Haughton 1987). Continued subsidies effectively lowered the operational cost of the fishermen allowing them to remain in the industry despite declining catches. Dynamite remained a large problem and long lining gained importance in offshore fishing.

The first major modern fish stock assessment was conducted from 1969 to 1973 (Munro 1983). Not surprisingly, the report from these surveys found the fisheries of Jamaica to be severely overfished. Over the next two decades, multiple surveys were conducted on the reef fish populations of Jamaica: all shared conclusions regarding the dismal status of Jamaican fisheries and the need for stronger management (Koslow et al. 1988; Aiken et al. 1996; Clemetson et al. 1996). Koslow et al. (1988) recorded no large grouper species in 27 dives on south coast reefs and only one in 24 dives on the south-east Pedro banks. The largest fish, both piscivores and herbivores, previously caught regularly in the traps, "virtually disappeared from catches' in all study sites (Koslow et al. 1988). Low value trash fish (small fish, Sparidae and Gerreidae) comprised the majority of the trap catches in the early 1990s (Shaul and Reifsteck 1991). A comparison of trap and net hauls from 1995-1998 with the surveys in the 1970s shows changes in species diversity that reflected continued loss of predatory species and replacement by less valuable species (Aiken and Kong 2000). A study by Klomp et al. (2003) supported earlier findings that 'recruitment overfishing has nearly eliminated some of Jamaica's fish stocks.'

During the 1970-1980s, dramatic declines in coral cover were noted following hurricanes and disease outbreaks, which decimated the once-dominant coral, Acropora cervicornis and wiped out the sea urchin and the then dominant reef grazer, Diadema antillarum. In addition, bleaching events, coastal destruction of mangroves and decreased water quality all contributed to worsening health of the coral reef community. It was at this point that the indirect ecological consequences of the continued fishing pressure on Jamaican reefs were finally realized. Hughes (1994) hypothesized that the loss of large herbivorous fishes left the reefs entirely dependent upon Diadema to control algal overgrowth; loss of this species due to disease left the reefs susceptible to algal overgrowth and coral decline.
Comparison of fish families listed as abundant prior to the 20th century with surveys from Jamaica's north coast in 2005 (Newman et al. 2006) indicate that only three of 16 families can still be considered abundant today (Fig. 3). At least half of the families listed prior to the 20th century as abundant or common are now occasional, rare or were not seen at all. More than half of the families considered 'abundant' in the Ostionan Pre-Columbian middens were not seen in modern surveys (Fig. 3). Entire genera (such as Mycteroperca, Serranidae, large groupers) were missing from modern surveys, and those families still common were comprised of small species (such as Caranx ruber, Carangidae) or small individuals (Newman et al. 2006).

The six abundant/common families found in the 1960s (Haemulidae, Scaridae, Acanthuridae, Holocentridae, Chaetodontidae and Pomacanthidae) were still common or abundant in 2005 (Munro 1983; Newman et al. 2006) (Fig. 3).

\section{Discussion}

Fisheries science generally relies upon databases that cover time spans of less than 30 years but increasingly require input of a 'virgin stock biomass'

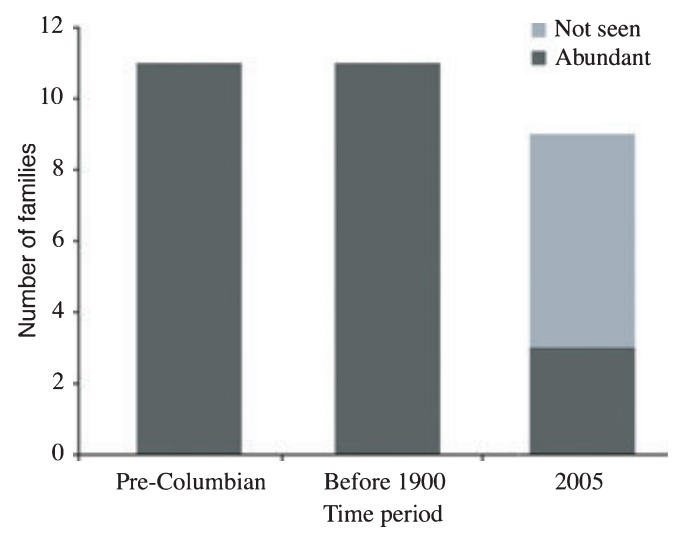

Figure 3 Comparison of family-level abundance through time. 'Before 1900' includes families listed as abundant between the years 1655-1900 and is based upon 14 separate references. The 2005 data are based on surveys conducted in Jamaica in February of 2005 (Newman et al. 2006). Families were categorized depending on the number of times recorded in 70 transects across 14 sites as follows: rare (0-1), occasional $(>1-10)$, common $(>10-$ $100)$ and abundant $(>100)$. Of the 11 families listed as abundant in 'Before 1900,' only three were still abundant in 2005 and six were not seen at all. 
Figure 4 Trajectory of reef fish abundance (solid line) and human population size (dashed line) through time. Note the break in the $X$-axis between AD 600-1400. (a) Marks the start of organized beach seines; (b) marks the introduction of chicken wire and $\mathrm{Z}$ traps; (c) marks the introduction of motorized canoes.

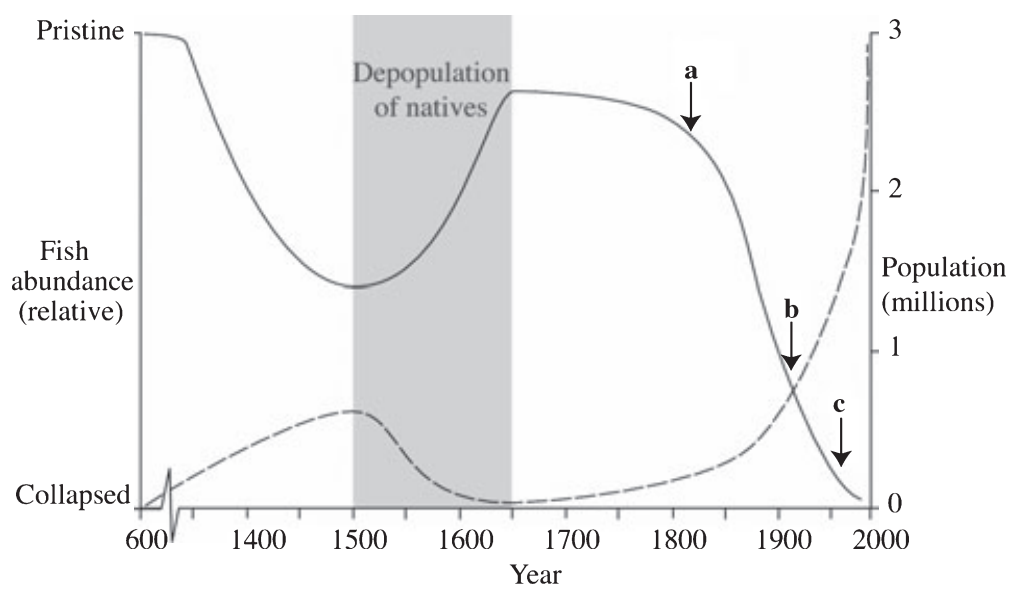

below what are often found today (Pinnegar and Engelhard 2008). Prehistoric declines in reef fish abundance in Jamaica are similar to those documented elsewhere in the Caribbean (Carlson and Keegan 2004; Wing and Wing 2001) and in the South Pacific (Butler 2001) and loss due to artisanal fisheries has been documented by modern ecological studies across the globe (Jennings and Polunin 1996; Hawkins and Roberts 2003). These studies examine through space what archaeological and historical analyses examine over time. Both approaches reveal that some of the biggest changes to reef fish communities occur at relatively low levels of fishing pressure (Jennings and Polunin 1996).

However, historical analysis of Jamaica reveals that changes in Jamaica's reef fish populations occurred not just due to modern artisanal fisheries, but also to a history of decline dating back to the 16 th to 19 th centuries and especially early 20th century (Figure 4). For managers, the results warn that seemingly low population densities may be more damaging than expected and may be confounded by changes that occurred decades before the perceived date of the established fishery.

This analysis also shows that cultural context, not just population size, is important for determining fishing pressure on reef fish. In Jamaica, finfish declines did not follow linearly with human population size because of the importation of salt fish and the historic use of provision grounds, which initially deflected pressure from reef fish even as human population soared. Similar cultural influence on fishing pressure has been found throughout the South Pacific where different island nations avoid certain species due to religious taboos (Dalzell 1998). negatively impacted by exploitation levels far 
In Jamaica, the narrow northern shelf exacerbated the effect of people and subtle technological change simply because the reef area was so limited (Munro 1983). Therefore, although freed slaves did not flock to seaside in large numbers, the small number of fishermen who did exist had a significant impact. Expanding on previous work (Jackson 1997), the detailed historical investigation reveals that, more than just salt fish imports, the unique opportunity for available land and geology of the reef led to the disconnect between population growth and reef fish declines.

The results indicate that technological innovation at any level and entrance of fishers into the fishery must be met with caution and constantly monitored for their effect on reef fish communities (Figure 4). Comparison of human population density, gear type and available reef area on modern reefs to past conditions on Jamaica's reefs may help managers identify corresponding stages in the trajectory of decline (or recovery) of a fishery and thereby help determine management actions - it is always easier to manage when there is some idea of where the ecosystem might be headed (Table 3).

Another benefit to historical analysis is that it can help identify previously unrecognized factors contributing to collapse. For instance, Jamaican recreational fisheries may have exacerbated declines as early as the 1940s. Although modern studies confirm the enormous impact of recreational fisheries on fish populations (Coleman et al. 2004), the long-term, cumulative effect of this additional source of mortality is largely unknown on many coral reef ecosystems and unaccounted for within fisheries management.

Table 3 Major technological/gear developments over each time period.

\begin{tabular}{|c|c|c|c|}
\hline & \multicolumn{3}{|l|}{ Period } \\
\hline & Ostionan/Meillacan 600-1500 (1-3) & Spanish 1509-1655 (4-6) & English 1656-1832 (1,7-8) \\
\hline Boats & $\begin{array}{l}\text { Dugout canoes, some held up to } 30-40 \\
\text { people and were } 96 \text { feet long }\end{array}$ & Dugout canoes & Dugout canoes \\
\hline Habitat & Potentially long distance and offshore & $\begin{array}{l}\text { Shoreline of beaches and } \\
\text { seagrass beds }\end{array}$ & Nearshore reef \\
\hline Nets & Vegetable fibre nets & & Cast nets \\
\hline Hook and Line & Present & Present & Present \\
\hline Traps & Present, likely arrowhead (chevron) design & & $\begin{array}{l}\text { Wicker pots approximately } \\
61 \mathrm{~cm}^{2} \times 30.5 \mathrm{~cm} \text { deep }\end{array}$ \\
\hline \multirow[t]{2}{*}{ Other } & $\begin{array}{l}\text { Bone-tipped spears, wood-bark poison, } \\
\text { remoras (Echeneidae)* }\end{array}$ & & \\
\hline & Post-Eman. 1833-1900 (7-10) & Trap Fishery 1901-1945 (11-12) & Modern 1946-2006 (13-15) \\
\hline Boats & Dugout canoes & $\begin{array}{l}\text { Some boats have spritsails, } \\
\text { one-masted boats called droghers } \\
\text { carry goods around the island }\end{array}$ & $\begin{array}{l}\text { Motorized canoes with } \\
\text { outboard engines }\end{array}$ \\
\hline Habitat & $\begin{array}{l}\text { Nearshore reef long lines set } \\
\text { up to a mile offshore }\end{array}$ & $\begin{array}{l}\text { Nearshore reefs up to } 3 \text { miles offshore, } \\
\text { excursions to Pedro Cays, some } \\
\text { offshore deep sea fishing }\end{array}$ & $\begin{array}{l}\text { Nearshore reefs, offshore } \\
\text { reefs, deep sea fishing } \\
\text { off shelf }\end{array}$ \\
\hline Nets & Beach seines, cast nets & Trammel nets, beach seines & Present \\
\hline Hook and Line & Present & Present & Present \\
\hline Traps & & $\begin{array}{l}Z \text { traps with chicken wire }(2 \times \text { size of } \\
\text { arrowhead traps), traps replace seines as } \\
\text { dominant form of fishing }\end{array}$ & $Z$ traps remain abundant \\
\hline Other & Palenkas - long lines & Grange spears (multiple prongs) & Spearfishing intensified \\
\hline
\end{tabular}

Sources given next to time period: (1) Sloane (1707-1725); (2) Black (1965); (3) Wilson (1997); (4) Fernández de Oviedo y Valdés and Pérez de Tudela y Bueso [1526 (1959)]; (5) Ober (1891); (6) Jackson (1924); (7) Gosse (1851); (8) Williams (1827); (9) Barclay (1828); (10) Rampini (1873); (11) Beckwith (1929); (12) Thompson (1945); (13) Munro et al. (1971); (14) Comitas (1962); (15) Munro (1983).

${ }^{*}$ Natives tied ropes around remoras and used them to latch onto bigger fish and haul them in (1). 
History also shows the importance of effective government response to documented ecosystem change. By ignoring recommendations from scientific advisors to limit the fishery in the mid-20th century, government actions in Jamaica spread the degradation to outer reefs and offshore banks, preventing possible recruitment from these regions to aid recovery of nearshore reefs. History implies that the current carrying capacity of Jamaican coral reefs appears insufficient to provide sustainable subsistence fishing for more than a handful of fishers. Therefore, focus on reducing pressure on the reefs, rather than expanding effort to offshore or deeper environments, is a more effective management strategy. Given the similar trajectories of decline in coral reef ecosystems around the world (Pandolfi et al. 2003) this strategy would probably work in other coral reef ecosystems.

The results imply that recovery is possible and historical analysis can inform realistic time frames for this recovery. During the 150 years following Spanish occupation, which was marked by drastically reduced human population size and a disinterest in local reef fish, large predatory fishes probably recovered so that early English colonists listed them as common catch by the late 17 th and early 18 th centuries. Modern reefs are far more degraded than in the past and face additional threats not present centuries ago. Nevertheless, these results, combined with modern studies of rapid recovery inside marine protected areas and following decreased fishing effort, show recovery is possible and offer insight into how long recovery may take to occur (Russ and Alcala 2003; Rosenberg et al. 2006).

In addition to informing time frames for recovery, there are many types of non-traditional data sources that have been successfully used to inform abundance and community structure targets for recovery including qualitative descriptions, quantitative records, geographic information, genetic data, archaeological middens and anecdotes (Jackson et al. 2001; Roman and Palumbi 2003; Lotze 2007; Sáenz-Arroyo et al. 2005; McClenachan et al. 2006a; Ainsworth et al. 2008; McClenachan and Cooper 2008). For historical ecology to be most effective at contributing to fisheries management, a combination of these approaches will prove most powerful.

For example, results from this study indicate that a large biomass of carnivorous and herbivorous reef fishes were a normal feature of
Jamaica's reefs until the end of the 19th century and describe the most common species. Another recent analysis estimates past abundances of the now extinct Caribbean monk seal based on records from historic observations and population models and gives quantitative estimates for the amount of reef fish required to sustain the historic seal population (McClenachan and Cooper 2008). This regional estimate $\left(732-1018 \mathrm{~g} \mathrm{~m}^{-2}\right)$ far exceeds any fish biomass currently found on Caribbean reefs but is similar to that found on remote Pacific reefs today (Sandin et al. 2008). The combined results from the two historical analyses and modern surveys of relatively undisturbed reefs, provides strong evidence that Caribbean reefs probably supported at least as great a biomass of fish and invertebrates as the most pristine living reefs of today. Taken together, this evidence allows fisheries managers to adjust goals for recovery of degraded reef fish populations in Jamaica, and sets a reference for reefs across the globe.

With only a handful of relatively pristine reefs left to study (Knowlton and Jackson 2008) we must rely upon all forms of data available in order to determine what factors contribute to healthy functioning, recovery and declines of coral reefs. By combining different historical and modern ecological approaches, estimates for past abundance and community structure can be refined. The results can then be used to refocus our perspective to achieve not only successful management but also basic ecological understanding of healthy coral reef ecosystems.

\section{Acknowledgements}

Published and unpublished data were generously provided by multiple researchers: S. O'Day, J. Allgood, L. Carlson, L. Comitas, B. Higman, J. Munro and K. Wesler. R. Hoffman, P. Holm, H. Lotze, K. Alexander, W. Leavenworth, J. Bolster, L. McClenachan, G. Paredes, M. Hardt, J. Jackson, E. Sala and D. Vickers provided critical feedback and helpful discussion on earlier manuscript versions. Thanks to Scripps Institution of Oceanography library staff, especially K. Rutlege, G. McCollough and archivist D. Day and R. L. Newman for digitizing photographs. All research conducted at the Center for Marine Biodiversity and Conservation, Scripps Institution of Oceangraphy. 


\section{References}

Aiken, K.A. and Haughton, M. (1987) Regulating fishing effort: the Jamaican experience. Proceedings of the 40th Gulf and Caribbean Fisheries Institute 40, 139-149.

Aiken, K.A. and Kong, G.A. (2000) The marine fisheries of Jamaica. Naga, The ICLARM Quarterly 23, 29-35.

Aiken, K.A., Koslow, A., Clementson, A., Auil, S., Espeut, P. and Galvex, F. (1996) The ICOD/UWI/Jamaica/ Belize Reef Fisheries Management Planning Project - a Caribbean cooperative research project. Proceedings of the 44th Gulf and Caribbean Fisheries Institute 44, 270282.

Aikman, A. (1787) An Abridgment of the Laws of Jamaica; Being an Alphabetical Digest of all the Public Acts of Assembly now in Force, from the Thirty-second Year of King Charles II. to the Thirty-second Year of ... George III. Inclusive, as Published in Two Volumes, Aikman, St Jago de la Vega, Jamaica.

Ainsworth, C.H., Pitcher, T.J. and Rotinsulu, C. (2008) Evidence of fishery depletions and shifting cognitive baselines in eastern Indonesia. Biological Conservation 141, 848-859.

Allgood, J. (2002) Faunal Analysis of the Green castle Estate Assemblage (STM25), St Mary Parish, Jamaica.

Andrews, K.R. (1959) The English Privateering Voyages to the West Indies 1588-1595. Hakluyt Society, Cambridge.

Aronson, R.B., Bruno, J.F., Precht, W.F. et al. (2003) Causes of coral reef degradation. Science 302, $1502-$ 1504.

Barclay, A. (1828) A Practical View of the Present State of Slavery in the West Indies, or An Examination of Mr. Stephen's "Slavery of the British West India Colonies" Containing More Particularly an Account of the Actual Condition of the Negroes in Jamaica. Smith, Elder and Co., London.

Beckwith, M.W. (1929) Black Roadways: A Study of Jamaican Folk Life. University of North Carolina Press, Chapel Hill, NC.

Bigelow, J. [1970 (1871)] Jamaica in 1850 or, the Effects of Sixteen Years of Freedom on a Slave Colony. Negro University Press, Westport, CT.

Black, C. (1965) The Story of Jamaica from Prehistory to the Present. Collins, London.

Butler, K.M. (1995) The Economics of Emancipation: Jamaica and Barbados, 1823-1943. University of North Carolina Press, Chapel Hill, NC.

Butler, V. (2001) Changing fish use on Mangaia, southern Cook Islands: resource depression and the prey choice model. International Journal of Osteoarchaeology 11, 88100.

Carlson, L. (2001) Zooarchaeological Analysis of the 2001 Excavations at Paradise Park, Westmoreland Parish, Jamaica. Florida Museum of Natural History, Caribbean Range, University of Florida, Gainesville, FL.
Carlson, L. (2002) Zooarchaeological Analysis of the Green Castle Site (STM25) Anotto Bay, St. Mary Parish, Jamaica. Southeastern Archaeological Research Inc., Gainesville, FL.

Carlson, L.A. and Keegan, W.F. (2004) Resource depletion in the prehistoric north West Indies. In: Voyages of Discovery (ed. S. Fitzpatrick). Praeger Publishers, Westport, CT, pp. 85-107.

Clemetson, A., Aiken, K.A. and Koslow, T. (1996) A preliminary investigation of fishery catch and effort on the Jamaican south coast and on Pedro bank. Proceedings of the 44th Gulf and Caribbean Fisheries Institute $\mathbf{4 4}$, 714-735.

Coleman, F.C., Figueira, W.F., Ueland, J.S. and Crowder, L.B. (2004) The impact of United States recreational fisheries on marine fish populations. Science 305, 1958 1960.

Collier, H.C. (1938) Fish and seaman's chips. Canada West Indies Magazine 27, 23-26.

Colonial Secretary (1911) Census: Jamaica and its Dependencies, Taken on the 3rd of April, 1911. General Register Office, Spanish Town.

Colonial Secretary (1921) Census: Jamaica and its Dependencies Taken on the 25th of April, 1921. General Register Office, Spanish Town.

Comitas, L. (1962) Fishermen and Cooperation in Rural Jamaica Anthropology. Columbia University, New York.

Craton, M. and Walvin, J. (1970) A Jamaican Plantation: The History of Worthy Park 1670-1970. University of Toronto Press, Toronto.

Crosby A.W. Jr (2003) The Columbian Exchange, 2nd edn. Praeger Publishers, Westport, CT.

Dalzell, P. (1998) The role of archaeological and culturalhistorical records in long-range coastal fisheries resources management strategies and policies in the Pacific Islands. Ocean and Coastal Management 40, 237252.

Dampier, W. [1729 (1968)] A New Voyage Around the World. Dover, New York.

Dayton, P.K., Tegner, M.J., Edwards, P.B. and Riser, K.L. (1998) Sliding baselines, ghosts, and reduced expectations in Kelp forest communities. Ecological Applications 8, 309-322.

Duerden, J.E. (1901) The marine resources of the British West Indies. West Indian Bulletin: the Journal of the Imperial Agricultural Department for the West Indies 2 , 121-141.

Dunn, R.S. (1972) Sugar and Slaves. The University of North Carolina Press, Chapel Hill, NC.

Fernández de Oviedo y Valdés, G. and Pérez de Tudela y Bueso, J. [1526 (1959)] Historia General Natural de las Indias, 5 volumes. Ediciones Atlas, Madrid,

Gardner, W.J. (1909) A History of Jamaica from its Discovery by Christopher Columbus to the Year 1872. T. Fisher Unwin, London. 
Gordon, H. (1964) A note on Jamaica's marine fisheries (commentary). Caribbean Quarterly 10, 41-49.

Gosse, P.H. (1851) A Naturalist's Sojourn in Jamaica. Longman, Brown, Green and Longmans, London.

Hawkins, J.P. and Roberts, C.M. (2003) Effects of artisanal fishing on Caribbean coral reefs. Conservation Biology 18 , 215-226.

Henderson, J. (1909) Peeps at Many Lands: Jamaica. Adam and Charles Black, London.

Hickling, C.F. (1949) The Fisheries of the British West Indies, Report on a Visit in 1949. Development and Welfare in the West Indies Bulletin 29, 21-26.

Higman, B. (1976) Characteristic Traits of the Creolian and African Negroes in Jamaica, etc. 1797. Caldwell Press, Mona.

Higman, B. (1980) The Jamaican Censuses of 1844 and 1861. University of the West Indies, Mona.

Higman, B. (1998) Montpelier Jamaica: A Plantation Community in Slavery and Freedom 1739-1912. Press University of the West Indies, Kingston.

Hughes, T.P. (1994) Catastrophes, phase shifts, and largescale degradation of a Caribbean coral reef. Science $\mathbf{2 6 5}$, 1547-1551.

Innis, H.A. (1954) The Cod Fisheries: The History of an International Economy. University of Toronto Press, Toronto,

Jackson, W. (1924) The Voyages of Captain William Jackson. The Offices of the Society, London.

Jackson, J.B.C. (1997) Reefs since Columbus. Coral Reefs 16, S22-S33.

Jackson, J.B.C., Kirby, M., Berger, W. et al. (2001) Historical overfishing and the collapse of coastal ecosystems. Science 293, 629-638.

Jennings, S. and Polunin, N.V.C. (1996) Effects of fishing effort and catch rate upon the structure and biomass of Fijian reef fish communities. Journal of Applied Ecology 33, 400-412.

Keegan, W. (2000) West Indian archaeology 3: ceramic age. Journal of Archaeological Research 8, 135-167.

King, F.W. (1981) Historic review of the decline of the green turtle and the Hawksbill. In: Biology and Conservation of Sea Turtles (ed. K.A. Bjorndal). Smithsonian Institution Press, Washington, DC, pp. 183-188.

Kirton, A. (1961) Fisheries development in Jamaica. The West Indies Fisheries Bulletin 6, 10-15.

Klomp, K.D., Clarke, K., Marks, K. and Miller, M. (2003) Condition of reef fish on Jamaica's north coast signals late stages of overexploitation. Proceedings of the 54th Gulf and Caribbean Fisheries Institute 54, 592-608.

Knowlton, N. and Jackson, J.B.C. (2008) Shifting baselines, local impacts, and global change on coral reefs. PLoS Biology 6, e54 (215-220).

Koslow, J.A., Hanley, F. and Wicklund, R. (1988) Effects of fishing on reef fish communities at Pedro Bank and Port Royal Cays, Jamaica. Marine Ecology Progress Series 43 , 201-212.
Kurlansky, M. (1997) Cod: the Biography of the Fish that Changed the World. Walker and Company, New York.

Lapointe, B.E. (1997) Nutrient thresholds for bottom-up control of macroalgal blooms on coral reefs in Jamaica and southeast Florida. Limnology \& Oceanography 42 , 1119-1131.

Las Casas, B. [1552 (1974)] The Devastation of the Indies: A Brief Account. Seabury Press, New York.

Leader, A. (1907) Through Jamaica with a Kodak. Simpkin, Marshall, Hamilton, Kent and Co Ltd, London.

Lee, G. (1933) Big game fishing in Jamaica. The West India Committee Circular 48, 5-7.

Lewis, M. (1834) Journal of a West Indian Proprietor: Kept During a Residence in the Island of Jamaica. John Murray, London.

Long, E. (1774) The History of Jamaica, or General Survey of the Ancient and Modern State of the Island. Frank Cass, London.

Lotze, H.K. (2007) Rise and fall of fishing and marine resource use in the Wadden Sea, Southern North Sea. Fisheries Research 87, 208-218.

Marsden, P. (1788) An Account of the Island of Jamaica...By a Gentleman Lately Resident on a Plantation. Printed for the Author, Hodgson Newcastle.

McClenachan, L. and Cooper, A.B. (2008) Extinction rate, historical population structure and ecological role of the Caribbean monk seal. Proceedings of the Royal Society B 275, 1351-1358.

McClenachan, L., Jackson, J.B.C. and Newman, M.J.H. (2006a) Conservation implications of historic sea turtle nesting beach loss. Frontiers in Ecology and Environment 4, 290-296.

McClenachan, L., Newman, M. and Paredes, G. (2006b) Florida keys coral reef fish communities, then and now. Proceedings of the Gulf and Caribbean Fisheries Institute $\mathbf{5 9}$, $1-8$.

Munro, J.L. (1969) The sea fisheries of Jamaica: past, present and future. Jamaica Journal 3, 16-22.

Munro, J.L. (1983) Caribbean Coral Reef Fishery Resources ICLARM Studies Review 7, 1-276.

Munro, J.L., Reeson, P.H. and Gaut, V.C. (1971) Dynamic factors affecting the performance of the Antillean fish trap. Proceedings of the Gulf and Caribbean Fisheries Institute 23, 184-194.

Newman, M.J.H., Paredes, G., Sala, E. and Jackson, J.B.C. (2006) Structure of Caribbean coral reef communities across a large gradient of fish biomass. Ecology Letters $\mathbf{9}$, 1216-1227.

O'Day, S.J. (2001) Change in Marine Resource Exploitation Patterns in Prehistoric Jamaica: Human Impacts on a Caribbean Island Environment. Paper presented at the ICAZ Conference of Fish Remains Working Group, New Zealand, 8-15 October 2001.

Ober, F.A. (1891) The Knockabout Club on the Spanish Main. Estes and Lauriat, Boston, MA. 
Olsen, D., Ammann, A. and LaPlace, J. (1978) Mesh selectivity of West Indian fish traps. Marine Fisheries Review 40, 15-16.

Pandolfi, J.M., Bradbury, R.H., Sala, E. et al. (2003) Global trajectories of the long-term decline of coral reef ecosystems. Science 301, 955-958.

Parsons, J.J. (1956) San Andres and Providencia: EnglishSpeaking Islands in the Western Caribbean. University of California Press, Berkeley, CA.

Pauly, D. (1995) Anecdotes and the shifting baseline syndrome of fisheries. Trends in Ecology and Evolution 10. 430 .

Pietersz, J.L. (1945-1948) Spanish documents relating to Jamaica. Jamaica Historical Review 1, 106-112.

Pinnegar, J.K. and Engelhard, G.H. (2008) The 'shifted baseline' phenomenon: a global perspective. Reviews in Fish Biology and Fisheries 18, 1-16.

Price, R. (1966) Caribbean fishing fishermen: a historical sketch. American Anthropologist 68, 1363-1383.

Rampini, C. (1873) Letters from Jamaica: the Land of Streams and Woods. Edmonston and Douglas, Edinburgh.

Roman, J. and Palumbi, S.R. (2003) Whales before whaling in the North Atlantic. Science 301, 508-510.

Rosenberg, A.A., Bolster, W.J., Alexander, K.E., Leavenworth, W.B., Cooper, A.B. and McKenzie, M.G. (2005) The history of ocean resources: modelling cod biomass using historical records. Frontiers in Ecology and Environment 3, 84-90.

Rosenberg, A.A., Swasey, J.H. and Bowman, M. (2006) Rebuilding US fisheries: progress and problems. Frontiers in Ecology and Environment 4, 303-308.

Rouse, I. (1992) The Tainos: Rise and Decline of the People who Greeted Columbus. Yale University Press, New Haven, CT.

Russ, G.R. and Alcala, A.C. (2003) Marine reserves: rates and patterns of recovery and decline of predatory fish, 1983-2000. Ecological Applications 13, 1553-1565.

Sáenz-Arroyo, A., Roberts, C.M., Torre, J. and CariñoOlvera, M.M. (2005) Fishers' anecdotes, naturalists' observations and grey reports to reassess marine species at risk: the case of the gulf grouper in Gulf of California, Mexico. Fish and Fisheries 6, 121-133.

Sáenz-Arroyo, A., Roberts, C., Torre, J., Cariño-Olvera, M. and Hawkins, J. (2006) The value of evidence about past abundance: marine fauna of the Gulf of California through the eyes of 16 th to 19 th century travellers. Fish and Fisheries 7, 128-146.

Sandin, S.A., Smith, J.E., Demartini, E.E. et al. (2008). Baselines and degradation of coral reefs in the northern line islands. PLoS ONE 3, e1548 (1-11).

Sary, Z., Munro, J.L. and Woodley, J.D. (2003) Status report on a Jamaican fishery: current value and the costs of non-management. Proceedings of the 54th Annual Gulf and Caribbean Fisheries Institute 54, 98-111.

Scudder, S. (1991) Early Arawak subsistence strategies on the south coast of Jamaica. Curacao, Netherlands Antilles. Reports of the Archeological-Anthropological Institute of the Netherlands Antilles, 9 pp.

Senior, B.M. (1969) Jamaica, As It Was, As It Is, and As It May Be. Negro University Press, New York.

Shaul, W. and Reifsteck, D. (1991) Comparison of catches by bamboo and wire fish traps in Jamaica. Proceedings of the 40th Gulf and Caribbean Fisheries Institute 40, 99107.

Sloane, H. (1707-1725) A Voyage to the Islands Madera, Barbadoes, Nieves, S. Christophers, and Jamaica..., 2 volumes. Printed by B.M. for the Author, London.

Stewart, J. [1823 (1969)] A View of the Past and Present State of the Island of Jamaica; with Remarks on the Moral and Physical Condition of the Slaves, and on the Abolition of Slavery in the Colonies. Negro University Press, New York.

Thompson, E.F. (1945) The fisheries of Jamaica. Development and Welfare in the West Indies Bulletin 18, 102.

Verrill, A.H. (1931) Jamaica of Today. Dodd Mead and Company, New York.

Watts, D. (1987) The West Indies: Patterns of Development, Culture, and Environmental Change Since 1942. Cambridge University Press, Cambridge.

Williams, C.R. (1827) A Tour Through the Island of Jamaica, From the Western to the Eastern End, in the Year 1823. Thomas Hurst, Edward Change, and Co., London.

Wilson, S.M. (1997) The Indigenous People of the Caribbean. University of Florida Press, Gainesville, FL.

Wing, S.R. and Wing, E. (2001) Prehistorical fisheries in the Caribbean. Coral Reefs 20, 1-8.

Woodley, J.D., Chornesky, E.A., Clifford, P.A. et al. (1981) Hurricane Allen's impact on Jamaican coral reefs. Science 214, 749-755. 